\title{
Functional responses of immature stages of Propylea quatuordecimpunctata (Coleoptera: Coccinellidae) to Aphis fabae (Hemiptera: Aphididae)
}

\author{
Nickolaos E. PAPANIKOLAOU ${ }^{1,2}$, ANGeLIKI F. MARTINOU ${ }^{1}$, Dimitrios C. KONTODIMAS ${ }^{1}$, \\ YiAnNIS G. MATSINOS² and PANAGIOTIS G. MILONAS ${ }^{1 *}$
}

\begin{abstract}
${ }^{1}$ Department of Entomology and Agricultural Zoology, Benaki Phytopathological Institute, St. Delta 8, 14561 Kifissia, Greece; e-mails: nepapanikolaou@yahoo.gr; kelly_martinou@yahoo.com; d.kontodimas@bpi.gr; p.milonas@bpi.gr

${ }^{2}$ Biodiversity Conservation Laboratory, Department of Environmental Sciences, University of the Aegean, Mytilene 81100, Greece; e-mail:matsinos@aegean.gr
\end{abstract}

Key words. Coccinellidae, Propylea quatuordecimpunctata, predator, aphid, Aphis fabae, predator-prey interaction, functional response in larvae

\begin{abstract}
Functional responses of immature stages of Propylea quatuordecimpunctata (L.) to varying densities of Aphis fabae Scopoli reared on Vicia faba L. were evaluated under laboratory conditions. All larval stages of the predator were starved for $12 \mathrm{~h}$ prior to being placed individually for $24 \mathrm{~h}$ in plastic containers with different densities of its prey, $A$. fabae, on potted $V$. faba plants. Logistic regression analysis of the proportion of aphids consumed as a function of initial density indicated that all larval instars of $P$. quatuordecimpunctata exhibited a type II functional response when searching for A. fabae on $V$. faba plants. Attack rates (0.059, $0.057,0.065$ and 0.064$)$ and handling times $(6.18,2.37,1.06$ and 0.44$)$ for first to fourth instar larvae, respectively, were estimated using Holling's disc equation.
\end{abstract}

\section{INTRODUCTION}

Critical aspects of predator and prey interactions can be determined by examining the relationship between predator feeding behaviour and the density of prey (Livdahl \& Stiven, 1983). The number of prey attacked per predator as a function of prey density is known as the functional response (Solomon, 1949; Holling, 1959). Although there are several types (curves) of functional response (van Alphen \& Jervis, 1996) most ecological interest is in Holling's type II and III functional responses, in which predators cause negative (type II) or positive (type III) density dependent mortality of their prey. In type II functional response prey consumption increases asymptotically to a plateau with increasing prey density, while in type III prey consumption is S-shaped (sigmoid) with increasing prey density.

Aphidophagous ladybirds have received considerable attention as biocontrol agents. The value of their predation efficiency varies from a minor role to significant reductions leading to within-season control (Obrycki et al., 2009). Desirable characteristics such as ability to feed on a variety of prey or being very voracious make them quite popular biocontrol agents (Hagen \& van den Bosch, 1968; Hodek \& Honěk, 1996). The fourteen-spotted ladybird beetle, Propylea quatuordecimpunctata (L.), is an aphidophagous coccinellid, widely distributed in the Palearctic region. It has also been established in the Nearctic region (Day et al., 1994). In Greece it is found in several habitats, such as citrus orchards, tobacco fields, cereals and cotton, preying on various species of aphids (Kavalli- eratos et al., 2004a, b; Kontodimas et al., 2008; Katsarou et al., 2009). The black bean aphid (Aphis fabae, Scopoli), is a common aphid pest of several cultivated and native plants and it is used as prey for rearing many coccinellid species, including $P$. quatuordecimpunctata used in biocontrol (Hodek, 1996). Biological control of aphids is regularly applied in greenhouses and open field crops (Hodek \& Honěk, 1996). However, there is an increasing need to evaluate more aphidophagous insects, so that more biocontrol options will be available for aphid population suppression under different management regimes.

In the present study, the effect of the density of $A$. fabae on the number caught and consumed by the four larval stages of $P$. quatuordecimpunctata was evaluated by determining the shape of their functional response to prey density and their attack rate coefficients and handling times. Attack rate describes the steepness of increase in predation with increasing prey density and handling time is useful for estimating the satiation threshold (Pervez \& Omkar, 2005). Functional response curves are used to understand the basic mechanisms that drive the interactions of predator-prey behaviour, to clarify coevolutionary relationships and to improve practical predictive powers for biological control (Houck \& Strauss, 1985; Martinou et al., 2010).

\section{MATERIAL AND METHODS}

\section{Insect culture}

An A. fabae colony originated from a stock colony reared at the Biological Control Laboratory, Benaki Phytopathological

\footnotetext{
* Coresponding author, e-mail: p.milonas@bpi.gr
} 
TABLE 1. Estimates of the parameters $P_{0}, P_{1}, P_{2}$ and $P_{3}( \pm \mathrm{SE})$ of the logistic regression analysis of the proportion of $A$. fabae prey consumed by $P$. quatuordecimpunctata larvae.

\begin{tabular}{ccccc}
\hline Parameter & $1^{\text {st }}$ instar & $2^{\text {nd }}$ instar & $3^{\text {rd }}$ instar & $4^{\text {th }}$ instar \\
\hline$P_{0}$ & $-0.4950 \pm 0.1372$ & $0.2997 \pm 0.1372$ & $0.6064 \pm 0.1102$ & $1.8144 \pm 0.1648$ \\
$P_{1}$ & $-7.5473 \pm 0.8881^{*}$ & $-10.3960 \pm 0.8809^{*}$ & $-11.3283 \pm 0.7003^{*}$ & $-11.2963 \pm 1.0128^{*}$ \\
$P_{2}$ & $2.7747 \pm 0.8923$ & $4.3932 \pm 0.8313$ & $4.5492 \pm 0.6472$ & $2.0225 \pm 0.9340$ \\
$P_{3}$ & $-0.9239 \pm 0.8870$ & $-2.2663 \pm 0.7352$ & $-1.9431 \pm 0.5463$ & $1.6707 \pm 0.8106$ \\
\hline
\end{tabular}

*Significant at $P<0.001$.

Institute on Vicia faba L. plants kept at $20 \pm 1{ }^{\circ} \mathrm{C}(65 \pm 2 \% \mathrm{RH}$, $16 \mathrm{~L}$ : 8D. P. quatuordecimpunctata was collected from Zea mays L. plants infested with Rhopalosiphum maidis Fitch in Arta County (Northwestern Greece). The coccinellid was reared in large cylindrical Plexiglass cages $(50 \mathrm{~cm}$ length $\times 30 \mathrm{~cm}$ diameter) containing $A$. fabae prey on potted $V$. faba plants at $25 \pm 1{ }^{\circ} \mathrm{C}, 65 \pm 2 \% \mathrm{RH}$ and a photoperiod of $16 \mathrm{~L}: 8 \mathrm{D}$.

\section{Functional response experiments}

The experiments were carried out under laboratory conditions at $20 \pm 1{ }^{\circ} \mathrm{C}, 65 \pm 2 \% \mathrm{RH}$ and a $16 \mathrm{~L}: 8 \mathrm{D}$ photoperiod. $P$. quatuordecimpuctata individuals used for the experiments were obtained from a colony reared for two generations at $20 \pm 1{ }^{\circ} \mathrm{C}$, $65 \pm 2 \% \mathrm{RH}$ and 16L : 8D photoperiod. All larval stages of $P$. quatuordecimpunctata were starved for $12 \mathrm{~h}$ and placed individually in plastic containers $(12 \mathrm{~cm}$ height $\times 7 \mathrm{~cm}$ diameter $)$ with various densities of immature stages of $A$. fabae (3-3.5 day-old) on potted $V$. faba plant hosts. After $24 \mathrm{~h}$ the predators were removed and the number of aphids remaining counted. Ten to fifteen day-old plants were used $(8-9 \mathrm{~cm}$ heigh with top growth removed). Prey densities were: $2,4,8,16$ and 32 aphids for first instar P. quatuordecimpunctata; 2, 4, 8, 16, 32 and 64 aphids for second instar P. quatuordecimpunctata; and 4, 8, 16, 32, 64 and 128 aphids for third and fourth instar P. quatuordecimpunctata. There were ten replicates of each prey density.

\section{Data analysis}

As the dependent variable is dichotomous (each aphid is alive or dead at the end of the trial), a logistic regression analysis of proportion of aphid eaten versus initial aphid density was used to determine the shape of the functional response (Trexler et al., 1988). A polynomial function (Juliano, 2001) was fitted using $R$ version 2.0.1 (R Development Core Team, 2008):

$$
\frac{N_{e}}{N_{0}}=\frac{\exp \left(P_{0}+P_{1} N_{0}+P_{2} N_{0}^{2}+P_{0}^{3} N_{0}^{3}\right)}{1+\exp \left(P_{0}+P_{1} N_{0}+P_{2} N_{0}^{2}+P_{3} N_{0}^{3}\right)}
$$

where $N_{e}$ is the number of aphids eaten; $N_{0}$ is the initial aphid density; $P_{0}, P_{1}, P_{2}$ and $P_{3}$ are the constant, linear, quadratic and cubic parameters, respectively, related to the slope of the curve. The above parameters were estimated using the method of maximum likehood and used to determine the shape of the functional response (Juliano, 2001).

The data indicated a type II functional response and were fitted to Holling's disc equation (Holling, 1959), which does not

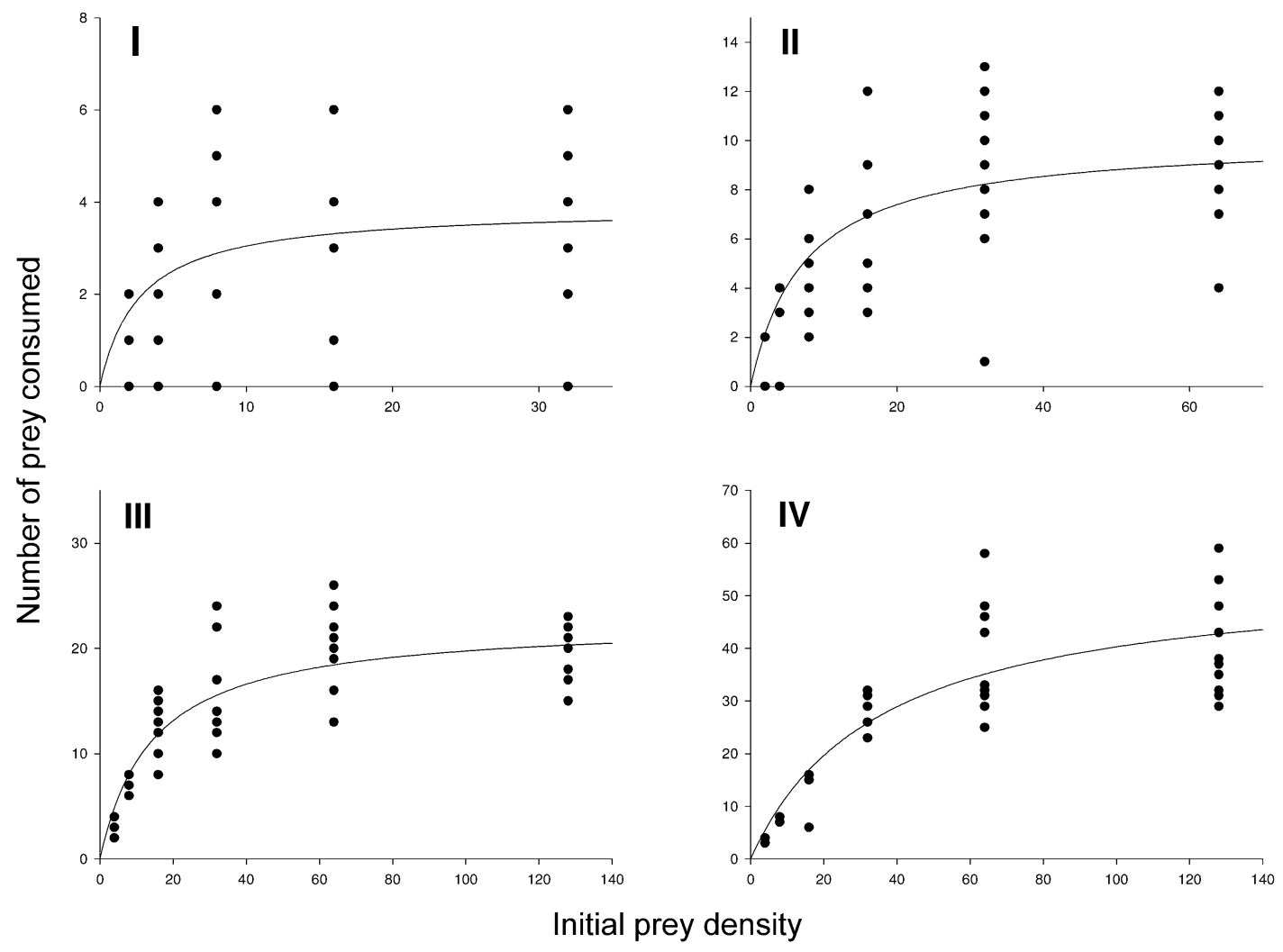

Fig. 1. Functional responses of the immature stages of $P$. quatuordecimpunctata to $A$. fabae on potted $V$. faba plants. I - first instar larva; II - second instar larva; III - third instar larva and IV - fourth instar larva. Data fitted using Holling's disc equation (Holling, 1959). 
TABLE 2. Parameters estimated by the Holling's disc equation.

\begin{tabular}{|c|c|c|c|c|c|}
\hline \multirow{2}{*}{ Larval stage } & \multicolumn{2}{|c|}{ Attack rate $\left(\mathrm{h}^{-1}\right)(a)$} & \multicolumn{2}{|c|}{ Handling time $(\mathrm{h})\left(T_{h}\right)$} & \multirow[t]{2}{*}{$R^{2}$} \\
\hline & Mean \pm S.E. & $95 \% \mathrm{CI}$ & Mean \pm S.E. & $95 \% \mathrm{CI}$ & \\
\hline $1^{\text {st }}$ instar & $0.0587 \pm 0.0254$ & $0.0078-0.1098$ & $6.1790 \pm 0.8526$ & $4.4657-7.8923$ & 0.1776 \\
\hline $2^{\text {nd }}$ instar & $0.0572 \pm 0.0120$ & $0.0332-0.0812$ & $2.3737 \pm 0.1983$ & $1.9770-2.7704$ & 0.5577 \\
\hline $3^{\text {rd }}$ instar & $0.0652 \pm 0.0086$ & $0.0480-0.0824$ & $1.0620 \pm 0.0551$ & $0.9518-1.1722$ & 0.7711 \\
\hline $4^{\text {th }}$ instar & $0.0640 \pm 0.0080$ & $0.0480-0.0800$ & $0.4394 \pm 0.0332$ & $0.3730-0.5058$ & 0.8218 \\
\hline
\end{tabular}

allow for prey depletion and may yield inaccurate estimates of calculated parameters. Rogers' random predator equation (Rogers, 1972), was also used but provided an inadequate fit to the data, maybe because it yields biased estimates when all the prey are eaten within the observation interval and so, no valid information can be derived from the experiment (Jalali et al., 2010). The disc equation is:

$$
N_{e}=\frac{a T N_{0}}{1+a T_{h} N_{0}}
$$

where $a$ is the attack rate; $T_{h}$ is the handling time; $T$ is the total time the predator spent in the experimental arena (24 h). Fitting was performed using a non-linear least squares approach (Livdahl \& Stiven, 1983; R Development Core Team, 2008). Significant differences between the parameters of the functional response model for all larval stages were tested with the superposition of $95 \%$ confidence intervals criterion. Mean values of $T_{h}$ estimated by non-linear least squares regression were used to calculate maximum attack rates $T / T_{h}$ (Hassell, 2000), which is the maximum number of prey that can be attacked by a predator during the time interval considered.

\section{RESULTS AND DISCUSSION}

The estimated parameters from the logistic regression analysis of the proportion of $A$. fabae consumed by $P$. quatuordecimpunctata larvae indicate a type II functional response for all larval instars of this predator (Table 1). The linear coefficient $P_{1}$ is significantly negative for all larval instars $(P<0.001)$. Thus, the proportion of prey consumed declines monotonically with increase in the initial number of prey offered, indicating a type II fuctional response.

Holling's "disc equation" fits well the data for the immature stages of $P$. quatuordecimpunctata preying on A. fabae (Fig. 1). The variation in predation rates at different prey densities increased from the first to fourth instar (see values for $R^{2}$, Table 2). Estimated attack rates were similar for all larval instars, while handling times decreased as larval age increased (Table 2). In addition, a decrease in larval handling time indicates an increase in the upper level of the response, which is determined by the maximum attack rate $\left(T / T_{h}\right)$. Maximum attack rate values were $3.88,10.11,22.59$ and 54.61 for the first, second, third and fourth instars, respectively (Table 3 ).

The effect of the density of $A$. fabae on each larval instar of $P$. quatuordecimpunctata showed that the coccinellid causes an inverse density dependent mortality of its aphid prey. In an earlier study, Messina \& Hanks (1998) report that fourth instar larvae and adults of $P$. quatuordecimpunctata show a type II response when preying on Diuraphis noxia. They also show that plant characteristics may shape the functional response as adults show a type II response on Indian ricegrass and a type III response on crested wheatgrass, possibly due to density dependent changes in the proportion of aphids in refuges. This further indicates that a predator's functional response is driven by factors such as prey or plant species and their interaction suggesting that predator-prey interactions should be evaluated in different and diverse environmental scenarios.

Although various types of functional response are described for coccinellids (Hodek, 1996), type II is the most common. Type II functional responses are generally associated with invertebrate predators (Hassell et al., 1977) and they are also common among aphidophagous coccinellids. Thus, a type II response is recorded for fourth instar larvae and adults of Coccinella undecimpunctata L. feeding on Myzus persicae Sulzer (Cabral et al., 2009), all four larval stages and female adults of Harmonia axyridis Pallas feeding on Aphis gossypii Glover (Lee \& Kang, 2004), third instar larvae and adults of $H$. axyridis and Coccinella septempunctata L. feeding on $A$. glycines Matsumura (Xue et al., 2009), fourth instar larvae and female adults of Coleophora inaequalis F. feeding on Toxoptera citricida Kirkaldy (Wang \& Tsai, 2001), adults of Cheilomenes sulphurea Olivier feeding on A. fabae (Hodek et al., 1984) and female adults of Adalia bipunctata L. feeding on M. persicae (Jalali et al., 2010). This type of response may destabilize predatorprey interactions (Oaten \& Murdoch, 1975) and is theoretically less capable of suppressing prey populations compared to a type III functional response (Holling, 1965).

The increase in the number of aphids killed at high density may result in two different phenomena operating simultaneously (Hodek, 1996): Firstly, the ravenous coccinellids engorge on the first few prey they encounter but then become progressively less competent at exploiting prey. Secondly, the larvae may ingest substantially more than the minimum required for development when prey is abundant. It is true that in any functional response experiment the attack rate and handling time are not the same at the start and the end of the experiment. They also might

TABLE 3. Maximum attack rates $\left(T / T_{h}\right)$ estimated for all four larval stages of $P$. quatuordecimpunctata. Mean values of $T_{h}$ estimated by non-linear least squares regression using Holling's "disc equation".

\begin{tabular}{lcccc}
\hline & $1^{\text {st }}$ instar & $2^{\text {nd }}$ instar & $3^{\text {rd }}$ instar & $4^{\text {th }}$ instar \\
\hline Max. attack rate $\left(T / T_{h}\right)$ & 3.88 & 10.11 & 22.59 & 54.61 \\
\hline
\end{tabular}


change with prey density. However, their estimation based on average values permits the elucidation of predation components in a relatively simple but realistic way (Hassell et al., 1976).

Maximum attack rates recorded for the old larvae were greater than those recorded for young larvae, due to the higher requirements for food and energy of the old larvae. The attack rate determines how steeply the functional response curve rises with increasing prey density. The results revealed that the steepness did not differ among the four larval stages. This further indicates that the larvae have similar abilities to respond to increasing prey densities. Handling times decreased from the older to the younger larvae as expected due to the former's higher consumption of prey. Being larger gives them an advantage in subduing and consuming prey.

Functional response experiments conducted under laboratory conditions may not be representative of field conditions. According to Murdoch (1973) experimental arenas used in functional response experiments are too simple and small. Larvae and adults should be considered as two different entities as larvae are more likely to stay in one patch of prey in the field, while adults may not (Kindlmann \& Dixon, 2001; Dostalkova et al., 2002). Patch in this sense means the space that the larva of a predator can reach by walking, usually one or a few adjacent plants, or even only a part of an individual plant. Thus, the functional response of a larva is determined by the situation encountered in the patch of prey it occupies while adults can easily fly from one patch to another (Kindlmann \& Dixon, 2001). Given this point, laboratory measured functional responses of immature coccinellids are close to their predation potential.

In the present study, the laboratory estimated functional responses of $P$. quatuordecimpunctata immature stages may be indicative of field conditions, especially at high prey densities, because coccinellids aggregate where prey is abundant (Dixon, 2000). The estimated handling times and maximum attack rates may be comparable with those achieved in the field where prey density is high and provides a basis for determining release rates appropriate for various aphid densities (Omkar \& Pervez, 2004; Jalali et al., 2010). These results provide a basic understanding of predator-prey interactions. However, additional parameters must be considered when evaluating $P$. quatuordecimpunctata as a potential biological control agent of $A$. fabae, because other biotic and abiotic factors also have a major influence on the efficiency of a predator in suppressing a pest population, such as the adults' functional response, numerical response, foraging behaviour and interference competition and should be the subject of future investigations.

ACKNOWLEDGEMENTS. This manuscript is part of the PhD study of NP. We would like to thank two anonymous reviewers for their positive comments.

\section{REFERENCES}

Cabral S., Soares A.O. \& Garcia P. 2009: Predation by Coccinella undecimpuctata L. (Coleoptera: Coccinellidae) on
Myzus persicae Sulzer (Homoptera: Aphididae): Effect of prey density. Biol. Control 50: 25-29.

Day W.H., Prokrym D.R., Ellis D.R. \& Chianese R.J. 1994: The known distribution of the predator Propylea quatuordecimpunctata (Coleoptera: Coccinellidae) in the United States, and thoughts on the origin of this species and five other exotic lady beetles in the eastern North America. Entomol. News 105: 244-256.

Dixon A.F.G. 2000: Insect Predator-Prey Dynamics. Ladybird Beetles and Biological Control. Cambridge University Press, Cambridge, UK, 257 pp.

Dostalkova I., Kindlmann P. \& Dixon A.F.G. 2002: Are classical predator-prey models relevant to the real world? $J$. Theor. Biol. 218: 323-330.

HAGEN K.S. \& VAN DEN BosCh R. 1968: Impact of pathogens, parasites and predators on aphids. Annu. Rev. Entomol. 13: 325-384.

Hassell M. 2000: The Spatial and Temporal Dynamics of HostParasitoid Interactions. Oxford University Press, Oxford, UK, 200 pp.

Hassell M.P., Lawton J.H. \& Beddington J.R. 1976: The components of arthropod predation I. The prey death-rate. $J$. Anim. Ecol. 45: 135-164.

Hassell M.P., Lawton J.H. \& Beddington J.R. 1977: Sigmoid functional responses by invertebrate predators and parasitoids. J. Anim. Ecol. 46: 249-262.

Hodek I. 1996: Food relationships. In Hodek I. \& Honěk A. (eds): Ecology of Coccinellidae. Kluwer Academic Publishers, Dordrecht, pp. 143-238.

HODEK I. \& HoNĚK A. 1996: Effectiveness and utilization. In Hodek I. \& Honěk A. (eds): Ecology of Coccinellidae. Kluwer Academic Publishers, Dordrecht, pp. 351-389.

Hodek I., Chakrabarti S. \& Rejmanek M. 1984: The effect of prey density on food intake by adult Cheilomenes sulphurea (Col.: Coccinellidae). Entomophaga 29: 179-184.

Holuing C.S. 1959: Some characteristics of simple types of predation and parasitism. Can. Entomol. 91: 385-398.

Holling C.S. 1965: The functional response of predators to prey density and its role in mimicry and population regulation. Mem. Entomol. Soc. Can. 45: 1-60.

Houck M.A. \& Strauss R.E. 1985: The comparative study of functional responses: experimental design and statistical interpretation. Can. Entomol. 117: 617-629.

Jalali M.A., Tirry L. \& De ClercQ P. 2010: Effect of temperature on the functional response of Adalia bipunctata to Myzus persicae. BioControl 55: 261-269.

Juliano S.A. 2001: Nonlinear curve fitting: predation and functional response curve. In Scheiner S.M. \& Gurevitch J. (eds): Design and Analysis of Ecological Experiments. Oxford University Press, New York, pp. 178-196.

Katsarou I., Martinou A., Papachristos D.P. \& Zoaki D. 2009: Toxic effects of insecticide residues on three aphidophagous coccinellid species. Hell. Plant Prot. J. 2: 101-106.

Kavallieratos N.G., Stathas G.J. \& Tomanovic Z. 2004a: Seasonal abundance of parasitoids (Hymenoptera: Braconidae, Aphidiinae) and predators (Coleoptera: Coccinellidae) of aphids infesting citrus in Greece. Biologia (Bratislava) 59: 191-196.

Kavallieratos N.G., Athanassiou C.G., Tomanovic Z., PapaDOPOulos G.D. \& VAYIAS B.J. 2004b: Seasonal abundance and effect of predators (Coleoptera, Coccinellidae) and parasitoids (Hymenoptera: Braconidae, Aphidiinae) on Myzus persicae (Hemiptera, Aphidoidea) densities on tobacco: a two-year study from Central Greece. Biologia (Bratislava) 59: 613-619. 
Kindlmann P. \& Dixon A.F.G. 2001: When and why top-down regulation fails in arthropod predator-prey systems. Basic Appl. Ecol. 2: 333-340.

Kontodimas D.C., Milonas P.G., Stathas G.J., Papanikolaou N.E., Skourti A. \& Matsinos Y.G. 2008: Life table parameters of the aphid predators Coccinella septempunctata, Ceratomegilla undecimnotata and Propylea quatuordecimpunctata (Coleoptera: Coccinellidae). Eur. J. Entomol. 105: 427-430.

LeE J.H. \& Kang T.J. 2004: Functional responses of Harmonia axyridis (Pallas) (Coleoptera: Coccinellidae) to Aphis gossypii Glover (Homoptera: Aphididae) in the laboratory. Biol. Control 31: 306-310.

Livdahl T.P. \& Stiven A.E. 1983: Statistical difficulties in the analysis of predator functional response data. Can. Entomol. 115: $1365-1370$.

Martinou A.F., Raymond B., Milonas P.G. \& Wright D.J. 2010: Impact of intraguild predation on parasitoid foraging behaviour. Ecol. Entomol. 35: 183-189.

Messina F.J. \& Hanks J.B. 1998: Host plant alters the shape of the functional response of an aphid predator (Coleoptera: Coccinellidae). Environ. Entomol. 27: 1196-1202.

MuRDOCH W.W. 1973: The functional response of aphid predators. J. Appl. Ecol. 10: 335-342.

Oaten A. \& Murdoch W.W. 1975: Functional response and stability in predator-prey systems. Am. Nat. 109: 289-298.

Obrycki J.J., Harwood J.D., Kring T.J. \& O’Neil R.J. 2009: Aphidophagy by Coccinellidae: Application of biological control in agroecosystems. Biol. Control 51: 244-254.
Omkar \& Pervez A. 2004: Functional and numerical responses of Propylea dissecta (Col., Coccinellidae). J. Appl. Entomol. 128: $140-146$.

Pervez A. \& Omkar 2005: Functional responses of coccinellid predators: an illustration of a logistic approach. J. Insect Sci. 5: $1-6$.

R Development Core Team 2008: $R$ : A Language and Environment for Statistical Computing. R Foundation for Statistical Computing, Vienna, Austria. URL http://www.R-project.org

ROGERS D. 1972: Random search and insect population models. J. Anim. Ecol. 41: 369-383.

Solomon M.E. 1949: The natural control of animal populations. J. Anim. Ecol. 18: 1-35.

Trexler J.C., McCulloch C.E. \& Travis J. 1988: How can the functional response best be determined? Oecologia 76: 206-214.

VAN AlPhen J.J.M. \& JERVIS M.A. 1996: Foraging behaviour. In Jervis M.A. \& Kidd N. (eds): Insect Natural Enemies: Practical Approaches to their Study and Evaluation. Chapman \& Hall, London, pp. 1-62.

WANG J.J. \& TSAI J.H. 2001: Development and functional response of Coelophora inaequalis (Coleoptera: Coccinellidae) feeding on brown citrus aphid, Toxoptera citricida (Homoptera: Aphididae). Agric. Forest Entomol. 3: 65-69.

Xue Y., Bahlai C.A., Frewin A., Sears M.K., Schaafsma A.W. \& Hallett R.H. 2009: Predation by Coccinella septempunctata and Harmonia axyridis (Coleoptera: Coccinellidae) on Aphis glycines (Homoptera: Aphididae). Environ. Entomol. 38: 708-714.

Received September 30, 2010; revised and accepted March 18, 2011 